\title{
Deposit Build-Up and Ash Behavior in Dual Fluid Bed Steam Gasification of Logging Residues in an Industrial Power Plant
} Matthias Kuba ${ }^{1 *}$, Hanbing $\mathrm{He}^{3}$, Friedrich Kirnbauer ${ }^{1}$, Dan Boström ${ }^{4}$, Marcus Öhman ${ }^{3}$, Hermann Hofbauer ${ }^{2}$

${ }^{1}$ Bioenergy 2020+ GmbH, Wiener Straße 49, A-7540 Güssing, Austria

${ }^{2}$ Vienna University of Technology, Institute of Chemical Engineering, Getreidemarkt 9/166, 1060 Vienna, Austria

${ }^{3}$ Energy Engineering, Division of Energy Science, Lulea University of Technology, SE-971 87 Lulea, Sweden

${ }^{4}$ Energy Technology and Thermal Process Chemistry, Umea University, SE-901 87 Umea, Sweden

*Corresponding author: matthias.kuba@bioenergy2020.eu; +43158801166323

\section{Abstract}

A promising way to substitute fossil fuels for production of electricity, heat, fuels for transportation and synthetic chemicals is biomass steam gasification in a dual fluidized bed (DFB). Using lower-cost feedstock, such as logging residues, instead of stemwood, improves the economic operation. In Senden, near Ulm in Germany, the first plant using logging residues is successfully operated by Stadtwerke Ulm. The major difficulties are slagging and deposit build-up. This paper characterizes inorganic components of ash forming matter and draws conclusions regarding mechanisms of deposit build-up. Olivine is used as bed 
material. Impurities, e.g. quartz, brought into the fluidized bed with the feedstock play a critical role. Interaction with biomass ash leads to formation of potassium silicates, decreasing the melting temperature. Recirculation of coarse ash back into combustion leads to enrichment of critical fragments. Improving the management of inorganic streams and controlling temperature levels is essential for operation with logging residues.

Keywords: Biomass gasification; deposit build-up; olivine; bed material agglomeration; logging residues

\section{Introduction}

A steadily rising $\mathrm{CO}_{2}$ concentration in the atmosphere, which is linked to climate change, has increased the demand for the development of multiple technologies using renewable energy sources. Using solid biomass as a resource is one way to raise the ratio of renewable energy in our energy system. As a $\mathrm{CO}_{2}$-neutral carbon source it is suited for usage in pyrolysis, gasification and combustion systems. Steam gasification of biomass is a promising technology for generating electricity and heat as well as synthetic products such as bio-fuels or chemicals. A dual fluidized bed (DFB) steam gasification process was developed at the Vienna University of Technology which is able to produce a product gas that can be further used to generate electricity, heat, fuels for transportation and synthetic chemicals. Thanks to the flexibility of the technology it can quickly adapt to changes in the energy market. The principle underpinning this process is the separation of endothermic gasification and exothermic combustion. Heat which is necessary for gasification is provided by a circulating bed material from the combustion to the 
50 gasification zone. Steam is used as fluidizing agent for the bubbling bed in the gasification zone. Fast fluidization in the combustion zone is realized by using air. Part of the biomass is combusted to provide the heat necessary for gasification [1-4]. Since 2001 the process has been successfully demonstrated at the biomass power plant in Güssing, Austria, which has a fuel power of 8 $\mathrm{MW}_{\text {th. }}$ In Oberwart, Austria, a biomass power plant with fuel power of $8.5 \mathrm{MW}_{\text {th }}$ has been in operation since 2007. At Senden, near Ulm in Germany, a plant with fuel power of $15 \mathrm{MW}_{\text {th }}$ has been in operation since 2011. Next generation dual fluid bed gasification is currently investigated at the Vienna University of Technology [5-7].

60 In contrast with all other gasification power plants the Senden plant is operated with logging residues together with wood chips as feedstock. As regards this lower-cost biomass, the major difficulties of operation are deposit build-up and slagging. Avoiding build-up of deposits may increase the availability and consequently the operation time further and is therefore important as regards the optimization of the plant. Previous studies showed an interaction between bed particles and ash during combustion of biomass feedstock. As a consequence of this interference calcium-rich layers are built around bed particles [8-10]. Investigations of time dependence regarding layer formation on quartz sand particles from a $30 \mathrm{MW}_{\text {th }}$ bubbling fluidized bed biomass combustion plant showed several steps of layer growth. On the first day of operation only one thin $\mathrm{Ca}$-, Si- and $\mathrm{K}$-rich homogeneous layer with a relatively high K/Ca molar ratio could be observed. Particles aged one day to two weeks 
73 also showed an outer Ca-rich layer. During the initial phase of layer formation,

74 the growth rate was relatively high, but decreased over time [11].

A correlation between bed particle layer formation and bed agglomeration has been established, mainly focusing on combustion of wood fuels $[8,9,12-15]$. Since layers on particles originate from biomass ash, they have a high probability of melting in zones of elevated temperatures. Partly melted layers act as glue and cause particles to stick together [16-18].Biomass ash leading to deposits has been investigated in the past for biomass combustion systems [19-23]. Depositions found in circulated fluidized bed combustion of woody biomass consisted mainly of bed particles embedded in a homogeneous melt. Potassium species from the feedstock interact with quartz sand bed particles to form sticky alkali-rich silicates. These sticky silicate melts can adhere to the walls of the cyclone or the return legs. Ordinary bed particles can deposit on the surface of those melts [24]. Impurities such as quartz and feldspar further enhance slag formation. [25-27]

Similar findings can be observed for dual fluid bed gasification of biomass. During long-term operation of the biomass DFB gasification plant in Güssing two calcium-rich layers formed on the bed material. The inner layer mainly consisted of calcium silicates and the outer layer had a composition similar to fine ash. The formation of calcium-rich layers is owed to the high calcium content of the woody feedstock and addition of calcium-rich additives to the reactor. This formation may arise from intensive contact with burning char particles. Molten ash components stick on the surface and calcium diffuses into the particles. The smooth surface of the layer indicates that the formation 
97 occurs with a molten surface [28]. Layers on olivine have a positive catalytic influence in the gasification process. They increase its catalytic activity enhancement of gasification reactions and reduce tar dramatically. Measurements at the biomass gasification reactor at the Vienna University of Technology showed a significant decrease of tars when layered olivine was used $[29,30]$. The water-gas-shift reaction is enhanced, which leads to higher hydrogen and carbon dioxide content in the product gas [31].

This paper focuses on the characterization of inorganic compounds in dual fluid bed biomass gasification of logging residues. X-ray fluorescence (XRF) analysis of different ash fractions in the systems was conducted. Results from these analyses were compared with other investigations with an environmental scanning electron microscope (ESEM) and X-ray diffraction (XRD). As a result, tracking of critical components regarding deposit built-up could be realized. Chemical equilibrium calculations were performed to evaluate melting behavior of compounds appertaining to slagging phenomena. Particle size fractionation enhanced knowledge of particle pathways in the system. Therefore, critical compounds could be assigned to certain parts of the reactor set-up. From the results of these analyses conclusions regarding the mechanisms of deposit build-up in the combustion area of the DFB system are drawn.

\section{Materials and Methods}

2.1 Description of the Industrial Biomass DFB Gasification Plant. Samples for investigation were taken from the biomass combined heat and power (CHP) plant in Senden, Germany. It has fuel power of $15 \mathrm{MW}_{\text {th }}$, generates electricity of about 5.1 $\mathrm{MW}_{\mathrm{el}}$ in two gas engines and an organic rankine cycle (ORC) and 
121 also produces district heating of about 6.4 $\mathrm{MW}_{\text {th. }}$ Logging residues, including 122 cut-off root ends, tops, and branches, are used as feedstock. This lower-cost feedstock comprises on average $15 \%$ of bark and $15 \%$ of needles; therefore,

124 only $70 \%$ of the used fuel is wood chips. Because of decentered chipping, 125 mainly by the forest industry, the particle size distribution and water content vary considerably. The feedstock is collected in four storage silos before it is fed into the biomass dryer. Hence, a good fuel mixing can be achieved before the feedstock is put into the gasifier. The specifications mentioned above are constantly monitored by a feedstock management process executed by the staff of the power plant on site.

131 Figure 1 shows a flow sheet of the power plant. Feedstock enters the gasification reactor via a screw conveyor, where the biomass is led directly into the bubbling fluidized bed. Therefore, gases released from the biomass are immediately in contact with catalytically active bed material. Olivine is used as bed material. It has two major roles in the process. First, it acts as a circulating heat carrier between the combustion reactor and the gasifier. Second, it performs as a catalyst regarding the decomposition of tars. The bubbling bed is kept at a temperature of around $850^{\circ} \mathrm{C}$ and steam is used as a gasifying agent.

Calcite is brought into the system as an additive to enhance the catalytic activity of the olivine. Bed material is transported together with char from the solid feedstock from the gasifier into the combustion reactor via a chute. In this zone air is used for fluidization and full oxidation is achieved. As a result, bed material particles are heated up and temperatures of up to $950^{\circ} \mathrm{C}$ are reached. After it 
material enters a cyclone which separates the bed material from flue gas. Small particles which are not separated from the gas stream by the cyclone enter the post-combustion chamber. Air is added at the inlet of the chamber to secure complete oxidation of flue gas. Since the post-combustion chamber is widened after the inlet, the gas stream is slowed down and further redirected by $180^{\circ}$ before leaving the chamber. The gas stream is then led through a radiation channel where the temperature of the flue gas is cooled down to about $630^{\circ} \mathrm{C}$. Particles in the gas stream are again divided by a gravitational separation unit. Bigger particles are recirculated back into the combustion reactor and are referred to as coarse ash. Smaller particles are dragged to a flue gas filter by the gas stream and are collected as fine ash. This fine ash is finally removed from the system.

Small biomass particles which are entrained out of the gasifier together with the product gas stream are referred to as fly coke. The product gas is cooled down by heat exchangers before passing through a product gas filter, where fly coke is separated. Impurities in the product gas which cannot be separated by the filter, such as tars, ammonia or sulfur components, are captured in a product gas scrubber filled with methyl ester of rapeseed (RME). Collected fly coke is transported back into the combustion reactor, since it still contains combustible compounds. The cleaned product gas is utilized in gas engines to generate electricity and heat. A small amount of product gas is brought back to control the temperature of the combustion zone. Used, layered olivine is periodically replaced by fresh olivine to make up bed material losses owed to attrition. 
168 Therefore used (aged) olivine is let out of the combustion reactor at the bottom and fresh olivine enters together with coarse ash and fly coke.

2.2 Sampling. Sampling was conducted during and after two different operation

171 periods. On both occasions the power plant was continuously operated for 172 around 1200 hours without cooling off. Figure 1 shows the sampling locations in 173 the power plant. Deposition samples were taken out of the post-combustion chamber on two different dates during the shutdown of the power plant after the operation periods. On each of the dates samples from three different positions were collected. From each position two samples were investigated. Thus, a total of 12 deposition samples were analyzed. Samples of bed material, coarse ash, fine ash, fly coke and feedstock were taken during the corresponding operation periods of the power plant which led to the build-up of the deposits. To obtain representative values samples from two different days of the operation period were collected. Sampling of bed material, coarse ash, fine ash and fly coke was conducted during steady-state operation. Bed material samples were collected at the bottom of the combustion reactor. Samples of coarse ash and fine ash were both taken after the gravitational separation of the two ash streams. The sampling point of the coarse ash was located below the gravitational separation chamber and that of the fine ash at the flue gas filter. Fly coke was collected from the product gas filter. Biomass feedstock was taken for every delivery at the power plant over a day. In total, eight trucks delivered the wood chips to the plant each day. A sample corresponding to the amount of biomass of the delivery was taken from each truck to collect a representative sample of biomass. 
2.3 Ashing of Feedstock. Feedstock samples were transformed into ash according to DIN CEN/TS 14775 . First, wood samples were heated to $250^{\circ} \mathrm{C}$ and the temperature level was maintained for 60 minutes. Second, the temperature was raised to $550^{\circ} \mathrm{C}$ and maintained until the feedstock was fully transformed into ash. The produced ash was then subjected to X-ray fluorescence (XRF) analysis.

2.4 XRF Analysis. Analysis of the elemental composition of the samples was carried out with XRF. Samples were melted in a Merck Spectromelt at $1050^{\circ} \mathrm{C}$ and placed on a stainless steel plate with a temperature of $400^{\circ} \mathrm{C}$. A PANalytical Axios Advanced analyzer was used to carry out the analysis. The analyzer worked under a vacuum atmosphere with a rhodium anode, an excitation voltage of $50 \mathrm{kV}$, and a tube current of $50 \mathrm{~mA}$. Results of $\mathrm{XRF}$ analysis indicated the elemental composition of the total sample calculated in oxides. Fly coke, fine ash, coarse ash, bed material and ash from feedstock were analyzed. From each of the fractions five samples for analysis were prepared. Furthermore, impurities separated from the olivine bed material were investigated. Separation was achieved by hand to ensure that the sample contained only impurities.

2.5 ESEM/EDS Analysis. Collected samples were mounted in epoxy, crosssectioned and polished. The chemical composition and morphology of the samples were determined by an environmental scanning electron microscope (ESEM) combined with energy dispersive X-ray spectroscopy (EDS). Elemental composition of different parts of the 12 deposits was determined by spot analysis of different fragments in the cross-section. Each fragment was 
analyzed at three or four different points (EDS spot analysis) and numerous

217 fragments from each sample were analyzed (more than 10 per sample). The collected data were then statistically evaluated. Corresponding bed material and coarse ash samples from the same operational time were analyzed in a similar manner. Bed material layers with different thicknesses were investigated in detail.

2.6 XRD Analysis. XRD data collections were performed with a Bruker d8 Advance instrument in $\theta-\theta$ mode with an optical configuration consisting of $\mathrm{Cu}$ Ka radiation, and a Vantec-1 detector. Continuous scans were made; therefore the total data collection time for each sample was more than $6 \mathrm{~h}$. The PDF-2 databank with Bruker software was used to gain initial qualitative identifications. The data were then further analyzed by the Rietveld technique and structure data from the Inorganic Crystal Structure Database (ICSD). As a result, semiquantitative information on the present crystalline phases was gained. In total, three deposit samples and two samples each of fly coke, fine ash, coarse ash and bed material were analyzed.

2.7 Optical Particle Size Fractionation. Particle size distribution was carried out with a Camsizer XT from Retsch Technologies. The camsizer uses dynamic image analysis (ISO 1322-2). In comparison with conventional particle size fractionation, such as sieving, dynamic image analysis delivers additional detailed particle shape information. Bed material and coarse ash samples were investigated and compared with each other with the same analysis settings. The measured parameters were the smallest diameter and the spherical equivalent 
239 diameter (area) with a selected measuring range between $1 \mu \mathrm{m}$ and $1.4 \mathrm{~mm}$.

240 Particles with a diameter above $1.4 \mathrm{~mm}$ were collected separately.

2412.8 Chemical Equilibrium Calculation. Chemical equilibrium model

242 calculations were performed to interpret the findings from experimental analysis

243 regarding melt fragments in the depositions and the coarse ash. Those

244 calculations were based on results gained from EDXS analysis of the samples.

245 Average values from the analyses were used. Fact-Sage 6.3 was used to

246 investigate the thermodynamic driving force behind the formation of melt

247 fragments. The program uses the minimization method of the total Gibbs free

248 energy of a chemical system. Thermodynamic data were employed from the

249 Fact database regarding gaseous compounds, stoichiometric condensed 250 phases and non-ideal solutions. Table 1 presents the data used in Fact-Sage

251 6.3. Calculations were performed for temperatures between $800{ }^{\circ} \mathrm{C}$ and 1100

$252{ }^{\circ} \mathrm{C}$ in $25^{\circ} \mathrm{C}$ steps with an access air ratio of 1.2 .

\section{3. Results}

254 An overview of the findings for each fraction based on the different analysis 255 methods is presented. The focus lies on the characterization of inorganic components in different fractions and the interaction between them.

\subsection{Ash of Feedstock}

Average results of the elemental composition of the collected feedstock ash samples are shown in Table 2. Only the main elements are displayed, and the mathematical remainder of 0.85 wt\% (called "others") includes the components $\mathrm{SnO}, \mathrm{MoO}_{3}, \mathrm{Nb}_{2} \mathrm{O}_{5}, \mathrm{ZrO}_{2}, \mathrm{PbO}, \mathrm{As}_{2} \mathrm{O}_{3}, \mathrm{ZnO}, \mathrm{CuO}, \mathrm{Co}_{3} \mathrm{O}_{4}, \mathrm{~V}_{2} \mathrm{O}_{5}, \mathrm{TiO}_{2}$, and $\mathrm{Cl}$. 
262 They are of no further interest regarding the investigation of deposit build-up and are therefore not included in the results of this paper.

264 The feedstock ash is characterized by comparably high amounts of $\mathrm{K}_{2} \mathrm{O}$ of about 12.6 wt $\%$ and relatively high amounts of $\mathrm{SiO}_{2}$ of about $13.4 \mathrm{wt} \%$. Ash from stemwood usually contains around $6 \mathrm{wt} \% \mathrm{~K}_{2} \mathrm{O}$ [32].

\subsection{Deposits}

$\mathrm{XRF}$ analysis of deposits as average value is shown in Table 2. Relatively high amounts of $\mathrm{SiO}_{2}, \mathrm{CaO}$ and $\mathrm{MgO}$ could be detected in the investigated samples. However, significant amounts of $\mathrm{K}_{2} \mathrm{O}$ over $5 \mathrm{wt} \%$ could also be found. Furthermore, amounts of more than $4 \mathrm{wt} \%$ of $\mathrm{Al}_{2} \mathrm{O}_{3}$ were detected.

Figure 2 show an ESEM/EDXS image of typical deposits in the post-combustion chamber. The black background is epoxy and therefore not the sample itself. It was possible to differentiate between particles - darker areas - which were embedded in a molten phase. Other areas showed higher amounts of molten fragments with different structures. Analysis of the darker areas showed typical composition of olivine particles. Around olivine particles an area with a composition typical of olivine layers could be detected [28]. Results of analyses are shown in Table 4. These layered particles were found embedded in a melt phase. Areas with high amounts of $\mathrm{Mg}$ characterize the surface of the outer particle layer. The morphology of these areas was less dense than that from the layers or the particle itself. Enrichment in Mg was not consistent everywhere. It varied heavily in terms of both thickness and coverage of the surface. The composition of the melt was not homogeneous for all investigated fragments. However, it was possible to differentiate between four types of 
fragments. Spot analysis showed that the composition of each of the types was homogeneous. Analyses of the fragments are presented in Table 4. Statistically, most of the fragments ( $75 \%)$ had the composition named deposit fragments $A$ and $\mathrm{B}$. Those fragments contained mainly $\mathrm{Ca}, \mathrm{Si}, \mathrm{Mg}, \mathrm{K}, \mathrm{Fe}, \mathrm{Al}$ and $\mathrm{O}$. The amount of potassium was either around 7.5 wt\% or around 3 wt $\%$. A significant amount ( 20\%) of the fragments showed the composition named deposit fragments $\mathrm{C}$. They are comparably high in Al and K. Only a comparably small percentage $(\sim 5 \%)$ of the investigated samples showed the composition named deposit fragments $\mathrm{D}$. No Mg could be detected in these fragments, and they are dominated by $\mathrm{Si}, \mathrm{Ca}$ and $\mathrm{O}$. Those four types $(\mathrm{A}, \mathrm{B}, \mathrm{C}, \mathrm{D})$ of fragments could be detected in all deposit samples. Regardless of the position of the deposit in the post-combustion chamber, the investigated samples showed similarities. Melt fragments attached to bed particles, as seen in Figure 2, were investigated in detail. These attached melt fragments had the same composition - shown in

Table 5 - as fragments A. The morphology of those attached fragments varied 301 heavily.

XRD analysis of deposits, as presented in Table 3, showed occurrence of crystal structures which are typical of olivine, such as forsterite, $\mathrm{Mg}_{2} \mathrm{SiO}_{4}$.

Compounds with $\mathrm{Ca}$ and $\mathrm{Si}$, such as larnite, $\mathrm{Ca}_{2} \mathrm{SiO}_{4}$, and especially wollastonite, $\mathrm{CaSiO}_{3}$, could be found. Furthermore, a significant number of compounds with $\mathrm{Ca}, \mathrm{Mg}$ and $\mathrm{Si}$ could be detected, such as akermanite, $307 \mathrm{Ca}_{2} \mathrm{MgSi}_{2} \mathrm{O}_{7}$, merwinite, $\mathrm{Ca}_{3} \mathrm{Mg}\left(\mathrm{SiO}_{4}\right)_{2}$ and bredigite, $\mathrm{Ca}_{7} \mathrm{Mg}\left(\mathrm{SiO}_{4}\right)_{4}$. In addition, comparably high amounts of kalsilite, $\mathrm{KAISiO}_{4}$, could be detected. The three samples were taken from different positions in the post-combustion chamber. 
310 Chemical equilibrium calculations of melted fragments in the deposits showed a

311 content of melt fractions of about 18 to 22 wt $\%$ for fragments $A$ and $B$. Those

312 are the fragments with higher potassium content. However, the difference

313 between those two fragments regarding the melt fraction is comparably low,

314 even though the potassium content varies from 7.7 wt\% in fragment $A$ to 16.9

315 wt\% in fragment $B$. The deposit melt fragments $C$ and $D$ possess a melt fraction

316 of 5 to $8.5 w t \%$. Increasing the temperature leads to rising numbers of melt

317 fragments, temperatures above $1000^{\circ} \mathrm{C}$ show the highest amounts of molten

318 fragments.

\section{$319 \quad 3.3$ Bed material}

320 Table 2 shows a typical elemental composition for used olivine, as already

321 known from previous work [29].

322 Typical back-scattered electron images of cross-sectional analysis with

323 ESEM/EDXS of bed material samples are shown in Figure 3. Bed material 324 samples were characterized by high numbers of olivine particles. The layers of 325 the particles differed in thickness, from fresher particles with no or only thin layers to older particles with thick layers. The composition of the inner and outer layers of the olivine particles is shown in Table 6. A smaller proportion of the investigated particles showed divergent composition. Those particles could be identified as quartz and feldspars amongst others and are further referred to as 330 impurities.

331 Corresponding to the findings from the XRF analysis bed material showed a comparably high correlation with findings from previous work on XRD analysis, as shown in Table 3 [29]. Two bed material samples were investigated. They 
334 are characterized by forsterite, $\mathrm{Mg}_{2} \mathrm{SiO}_{4}$, periclase, $\mathrm{MgO}$ and lime, $\mathrm{CaO}$. In 335 addition, around $3 \%$ of quartz could be detected. Traces of potassium could 336 only be detected in crystallite phases as for instance $\mathrm{K}_{2} \mathrm{MgSiO}_{4}$. This compound

337 is, however, only a suggestion and it cannot be stated with certainty that it really 338 occurs.

\section{$339 \quad 3.4$ Coarse ash}

340 Elemental analysis with XRF also shows a similar composition of coarse ash and bed material samples, with slightly higher amounts of $\mathrm{SiO}_{2}$ in the coarse ash. Impurities were analyzed in detail. Table 2 shows the elemental composition of the XRF analyses. The foreign matter was composed of a broader variety of elements than bed material or coarse ash. $\mathrm{Na}_{2} \mathrm{O}$ amounts to around 4 wt\% and $\mathrm{Al}_{2} \mathrm{O}_{3}$ amounts to around 5.5 wt\% could be detected. Furthermore, the $\mathrm{K}_{2} \mathrm{O}$ was elevated to values of around $8 \mathrm{wt} \%$.

Coarse ash samples showed higher amounts of impurities from the feedstock, such as quartz and feldspar particles, than the bed material samples. A typical cross-section image of the sample can be seen in Figure 4. It presents the diversity of different particles. Table 6 presents the composition of the inner and outer layers of those quartz and feldspar particles. Layers, especially the inner layers, of quartz and feldspars were significantly richer in potassium than those of olivine. In addition, melt fragments could be found in the sample. Two 354 different compositions could be detected and are also presented in Table 6. Melt fragments varied in size and shape; some of them were attached to particles or even caused agglomeration of particles. Olivine particles in the coarse ash were characterized by thick layers. In those thick layers cracks 
358 could be observed. The cracks could only be found in the layers, not in the 359 olivine particle itself. The particle surface, however, seems to be affected by the 360 formation of cracks. Even though the cracks seem to end at the surface, an 361 inner layer intrudes a little further into the particle at those spots. This 362 phenomenon was observed for numerous olivine particles in the coarse ash. 363 Figure 5 shows an example of an olivine particle with the described cracks in 364 the layer. Furthermore, a comparably high number of layer breakage areas could be detected in olivine particles in the coarse ash, but not for any of the impurities. These breakages could be detected for olivine with thick layers, as seen in Figure 6. The particle itself seems to be untouched, but part of the layer 368 is missing.

369 Results of XRD analysis of coarse ash are shown in Table 3. Two samples were investigated. A clear resemblance to the results for bed material analysis can be seen. High amounts of forsterite as well as lime and periclase 372 characterize the coarse ash samples. Chemical equilibrium calculations show 373 varying amounts of molten fractions at elevated temperatures. Coarse ash melt 374 fragments $A$ have a melt fraction of around 70 to $71 \mathrm{wt} \%$, whereas the melt 375 fraction in the fragments $B$ varies from 33 to 43 wt\%, rising with increasing 376 temperature.

377 The particle size distribution for coarse ash samples was compared with those 378 of bed material. The mean diameter $D_{50}$ of bed material for the spherical 379 equivalent diameter is about $605 \mu \mathrm{m}$ whereas that of coarse ash is about 490 380 $\mu \mathrm{m}$. The diameter $D_{50}$ for the minimal diameter is $535 \mu \mathrm{m}$ for the bed material and $430 \mu \mathrm{m}$ for the coarse ash. 
382 Both samples showed a homogeneous particle size distribution. The bed material sample contained impurities from the feedstock with diameters above 1 $\mathrm{mm}$. Those impure particles are referred to as coarse grains and were collected separately. The separation of the coarse grains from the rest of the bed material was performed so the samples could reasonably be compared with the coarse ash samples.

\subsection{Fine ash}

$\mathrm{XRF}$ analysis of fine ash is characterized by higher amounts of $\mathrm{CaO}$ and smaller amounts of $\mathrm{SiO}_{2}$ and $\mathrm{MgO}$ than bed material and coarse ash samples. Higher $\mathrm{K}_{2} \mathrm{O}$ amounts of around $3 \mathrm{wt} \%$ could also be found. Results are shown in Table 2. Corresponding to findings from XRF analysis, XRD results show high amounts of $\mathrm{CaO}$ and $\mathrm{CaCO}_{3}$, as presented in Table 3. Two samples were examined. In addition, Ca-Mg compounds such as merwinite or bredigite could be detected in elevated amounts. No presence of forsterite could be found in fine ash. Mg could also be detected as periclase, $\mathrm{MgO}$.

\subsection{Fly coke}

XRF analysis of fly coke, displayed in Table 2, also showed a resemblance to bed material samples. $\mathrm{MgO}, \mathrm{SiO}_{2}, \mathrm{CaO}$ and $\mathrm{Fe}_{2} \mathrm{O}_{3}$ are the main compounds. The elemental composition of the main ash forming elements is displayed in Table 2. XRD analysis of fly coke showed a high variation of different components (Table 3). Two samples were investigated. Compounds containing $\mathrm{Ca}$ are dominant, but kalsilite was present in higher amounts than in the ther samples.A comparably high variation of forsterite, $\mathrm{Mg}_{2} \mathrm{SiO}_{4}$, could be detected 
405 between the two samples. Calcite, $\mathrm{CaCO}_{3}$, and portlandite, $\mathrm{Ca}(\mathrm{OH})_{2}$, were also detected in different amounts.

407

\section{Discussion}

409 Findings from analyses of inorganic streams in the process are discussed in 410 detail. Deposition build-up in zones with elevated temperatures is connected 411 with inorganic materials in the system. Mechanisms leading to deposits are explained by outlining the interaction between biomass ash, mineral impurities and bed material particles.

414 The logging residues which are used as feedstock showed relatively high 415 amounts of potassium in comparison to average stemwood. This leads to comparably low melting temperatures of ash, making the char particles sticky at temperatures over $1000{ }^{\circ} \mathrm{C}$, as chemical equilibrium calculations have shown. At calculated temperatures above $1000^{\circ} \mathrm{C}$, increasing amounts of molten fragments were present in coarse ash and deposit samples. These calculations allow a prediction of deposit build-up regarding temperature variation. However, melting processes highly depend on inorganic compounds, such as potassium, and therefore, predictions can only be made if representative fuel analysis is available. Higher amounts of e.g. potassium in the fuel result in ash melting at lower temperature levels, since the system approaches its eutectic point. Phase diagrams of relevant mixtures regarding biomass ash are discussed in length by [33]. After shut-down those fragments are typically found in the cyclone and post-combustion chamber as deposits. Potassium is released from the char particle and occurs in liquid form [34]. Since the gas stream is slowed down by 
429 a widening in the post-combustion chamber and is further redirected by $180^{\circ}$, 430 particles can easily collide with the wall. These collisions lead to attachments of 431 sticky particles. Operational experience in the gasification power plant in 432 Senden, near Ulm, Germany, has shown noticeable deposition build-up in the 433 post-combustion chamber after operation times of around $1000-1200$ hours when temperature levels exceeded $1000^{\circ} \mathrm{C}$. Depositions were mainly found in the post-combustion chamber, but also in the cyclone to some extent. Furthermore, numerous impurities, such as quartz and feldspar particles, were brought into the gasifier together with the biomass feedstock. Potassium from the logging residues searches for reaction partners and can form silicates with the impurities. This leads to comparably high amounts of potassium in the layers of impurities. Potassium is involved in the layer formation of olivine, but is released from the particles during the process [28]. This could be verified, since the olivine layers did not show any potassium content. Therefore, the potassium which is bound in the feedstock has a high probability of reacting with impurities to form potassium-silicate compounds. Potassium reduces the melting temperature of the compound and is therefore critical as regards slagging and the build-up of deposits. Temperatures above $1000^{\circ} \mathrm{C}$ in the post-combustion chamber lead to melting of the potassium-rich layers of the impurities and, as a consequence, make them sticky. Fragments with high amounts of silica, aluminum and potassium are most likely formed through an interaction between biomass ash and impurities. XRD analysis showed comparably high amounts of kalsilite, $\mathrm{KAISiO}_{4}$, in the deposits, indicating that feldspars dissolved into the melt and formed new crystallite structures. 
453 The composition of the deposit fragments $C$ and $D$, as shown in Table 4, 454 indicates impurity-driven melting processes. Deposit fragments $\mathrm{C}$ are 455 characterized by higher amounts of aluminum and potassium, which indicates 456 that they originate from feldspar particles interacting with biomass ash. Deposit 457 fragments $D$ seem to be formed from an interaction between quartz particles 458 and biomass ash and therefore are characterized by higher amounts of silica 459 and calcium.

460 Deposit fragments $A$ and $B$ with magnesium amounts of around $10 \mathrm{wt} \%$ indicate 461 the presence of olivine in the melt. Olivine itself is not prone to forming deposits; 462 the particles are only embedded in a melt, as shown in Figure 2. Therefore, 463 depositions with significant amounts of magnesium ( 10 wt\%) have to emerge 464 from an interaction between olivine and impurity-driven melt, since significant 465 amounts of $\mathrm{Al}$ and $\mathrm{K}$ could also be detected in those fragments. XRD analysis showed significant amounts of compounds with $\mathrm{Si}$, $\mathrm{Ca}$ and $\mathrm{Mg}$, such as 467 akermanite, $\mathrm{Ca}_{2} \mathrm{MgSi}_{2} \mathrm{O}_{7}$, merwinite, $\mathrm{Ca}_{3} \mathrm{Mg}\left(\mathrm{SiO}_{4}\right)_{2}$ and bredigite, $468 \mathrm{Ca}_{7} \mathrm{Mg}\left(\mathrm{SiO}_{4}\right)_{4}$, which also indicates an interaction between olivine and biomass 469 ash. Two relevant observations regarding this interaction relate to the SEM analysis. First, on the surface of the outer layer of olivine particles, Mg-rich areas could be found. Since the morphology of those areas was less dense 472 than that from the layers, it seems that the high $\mathrm{Mg}$ content originates from 473 olivine attrition. This high $\mathrm{Mg}$ attrition accumulates on the surface of the outer particle layer, a phenomenon observed in deposition samples as well as in bed material and coarse ash samples (see Figure 5). Second, melt fragments attached to olivine particles showed exactly the same composition as deposition 
477 melt fragments $\mathrm{A}$, as seen in Table 5, with about $10 \mathrm{wt} \%$ of $\mathrm{Mg}$. Therefore, it is 478 likely that melts from biomass ash and layered impurities get stuck on the 479 olivine particles. Reaction with Ca-rich layers and Mg-rich areas seems to 480 proceed. These attached fragments can easily break off the olivine particle and 481 be found as fragments in the deposits. A high probability of breakage of these 482 fragments is further supported by another observation. Numerous breakage areas for aged olivine particles, as shown in Figure 6, could be detected in the coarse ash. Olivine itself seems to be resistant to the formation of cracks. Therefore, the tension which is built up by the growth process of the layers results in cracks which lead to breakage of part of the layer itself. If, additionally, melt fragments are attached to the layers, breakage along the cracks seems probable.

SEM analysis showed a greater variety of different particles in the coarse ash than in the bed material. Numerous melt fragments and layered impurities with high amounts of potassium could be found, but XRD analysis did not detect the presence of potassium in crystalline structures. Therefore, potassium seems to exist in an amorphous state rather than in crystallite structures. This indicates that melting processes proceed in the post-combustion chamber. Chemical equilibrium calculations also showed comparably high amounts of melt at elevated temperatures for those fragments because of the relatively high content of potassium. Only the presence of aluminum stabilizes the compound and raises the melting temperature. However, even the fragments with higher aluminum content, such as coarse ash fragments $B$, have an estimated melt 500 fraction of 33 to $43 \%$, depending on the temperature. As a result they become 
sticky in zones with elevated temperatures, such as the cyclone or the postcombustion chamber. Melted fragments which do not stick on the walls and start building deposits but leave the post-combustion chamber are recirculated to the combustion chamber with the coarse ash. As a consequence, they can cause agglomeration of bed particles. Keeping those fragments in the system increases the probability of deposition build-up even further.

Coarse ash also showed higher amounts of older olivine particles, characterized by thicker layers. These layers have a positive and a negative side regarding biomass gasification. On the one hand, the layers increase the catalytic activity of the bed material [30]. On the other hand, since layers originate from melting processes of biomass ash [28], they have a high probability of causing agglomeration and deposit build-up in zones with higher temperature. Particle size fractionation of bed material and coarse ash showed that the average particle diameter is significantly smaller for particles recirculated with the coarse ash. As a consequence, these particles have a higher probability of leaving the system through the cyclone and entering the post-combustion chamber before they can enter the gasification zone. Thus, a circulation of critical components in the coarse ash is created between the combustion chamber, the cyclone and the post-combustion chamber. This means that critical components, such as potassium-rich fragments leading to ash mixtures close to the eutectic point, are not only kept in the system, but seem to be mainly circulated in the combustion part of the dual fluidized bed. As a result, the recirculated particles have only a slight impact on the catalytic activity of the fluidized bed in the gasification zone as they are not frequently found there. 
525 The cyclone is a critical area in this process regarding inorganic components.

526 Temperatures between $950{ }^{\circ} \mathrm{C}$ and $1000^{\circ} \mathrm{C}$ are typical in this area during 527 operation of the gasification plant. Circulated bed material and circulated coarse 528 ash both pass through the cyclone and therefore make it vulnerable to deposits 529 in long-term operation. Deposits in the cyclone decrease the separation 530 efficiency and as a result bed material consumption rises. This leads to higher 531 amounts of mineral material in the post-combustion chamber and, as a 532 consequence, a higher probability of deposition build-up. Controlling the 533 temperature levels in the system is essential when logging residues are used. In 534 long-term operation the cyclone needs to be operated at temperatures below $535950^{\circ} \mathrm{C}$. To avoid an accumulation of critical compounds in the system, the coarse ash should be released from the system periodically.

537

\section{5. Conclusions}

539 Logging residues as lower-cost feedstock lead to higher amounts of potassium 540 and therefore the melting temperature of the ash is lower than that from 541 stemwood. Mineral impurities, e.g., quartz, are brought into the gasifier with the 542 feedstock. Interaction between impurities and biomass ash increases the risk of 543 deposit build-up.

544 In summary, the conducted work showed that dual fluid bed gasification of 545 logging residues with high potassium amounts is possible and was successfully 546 demonstrated at the CHP plant Senden, Germany. Knowledge of the above547 described mechanism of deposit build-up helps to increase the operation time 548 and reduces the risk of unplanned shutdowns. 


\section{Acknowledgements}

550 This study was carried out in the frame of the Bioenergy2020+ project "C-II-1-

551 24". Bioenergy2020+ $\mathrm{GmbH}$ is funded within the Austrian COMET program,

552 which is managed by the Austrian Research Promotion Agency (FFG) and

553 promoted by the federal government of Austria as well as the federal states

554 Burgenland, Niederösterreich and Steiermark. We are grateful for the support of 555 our project partners HGA Senden (Stadtwerke UIm), and the Institute of

556 Chemical Engineering at the Vienna University of Technology. Furthermore, we

557 would like to thank the Department of Energy Engineering, Division of Energy

558 Science, at the Lulea University of Technology, Sweden, as well as the

559 Department of Energy Technology and Thermal Process Chemistry at the

560 Umea University, Sweden, for their support.

561

562

\section{References}

[1] Hofbauer H, Rauch R, Löeffler G, Kaiser S, Fercher E, Tremmel H. Six years experience with the FICFB-gasification process. Proc. 12th Eur. Conf. Technol. Exhib. biomass energy, Ind. Clim. Prot., 2002.

[2] Kern S, Pfeifer C, Hofbauer H. Synergetic Utilization of Renewable and Fossil Fuels: Dual Fluidized Bed Steam Co-gasification of Coal and Wood. APCBEE Procedia 2012;1:136-40. doi:10.1016/j.apcbee.2012.03.022.

[3] Kern S, Pfeifer C, Hofbauer H. Gasification of wood in a dual fluidized bed gasifier: Influence of fuel feeding on process performance. Chem Eng Sci 2013;90:284-98. doi:10.1016/j.ces.2012.12.044.

Wilk V, Hofbauer H. Co-gasification of plastics and biomass in a dual fluidized-bed steam gasifier: Possible interactions of fuels. Energy and Fuels 2013;27:3261-73. doi:10.1021/ef400349k. 
[5] Schmid JC, Pröll T, Pfeifer C, Hofbauer H. Improvement of Gas - Solid Interaction in Dual Circulating Fluidized Bed Systems. Proc. 9th Eur. Conf. Ind. Furn. Boil. (INFUB), Estoril, Port. 2011, 2011, p. 1-13.

[6] Schmid JC, Pfeifer C, Kitzler H, Pröll T, Hofbauer H. A new dual fluidized bed gasifier design for improved in situ conversion of hydrocarbons. Proc. Int. Conf. Polygeneration Strateg., 2011, p. 1-10.

[7] Pfeifer C, Schmid JC, Pröll T, Hofbauer H. Next Generation Biomass Gasifier. Eur. Biomass Conf. Exhib. Berlin, Ger. 2011, 2011, p. 1-7.

[8] Brus E, Öhman M, Nordin A. Mechanisms of bed agglomeration during fluidized-bed combustion of biomass fuels. Energy and Fuels 2005;19:825-32. doi:10.1021/ef0400868.

[9] Grimm A, Öhman M, Lindberg T, Fredriksson A, Boström D. Bed agglomeration characteristics in fluidized-bed combustion of biomass fuels using olivine as bed material. Energy and Fuels 2012;26:4550-9. doi:10.1021/ef300569n.

[10] Kaknics J, Michel R, Richard A, Poirier J. High-Temperature Interactions between Molten Miscanthus Ashes and Bed Materials in a Fluidized-Bed Gasifier. Energy \& Fuels 2015;29:1785-92. doi:10.1021/ef502750t.

[11] He H, Boström D, Öhman M. Time dependence of bed particle layer formation in fluidized quartz bed combustion of wood-derived fuels. Energy and Fuels 2014;28:3841-8. doi:10.1021/ef500386k.

[12] Brus E, Öhman M, Nordin A, Boström D, Hedman H, Eklund A. Bed agglomeration characteristics of biomass fuels using blast-furnace slag as bed material. Energy and Fuels 2004;18:1187-93. doi:10.1021/ef034095c.

[13] Grimm A, Skoglund N, Boström D, Öhman M. Bed agglomeration characteristics in fluidized quartz bed combustion of phosphorus-rich biomass fuels. Energy and Fuels 2011;25:937-47. doi:10.1021/ef101451e.

[14] Serrano D, Sánchez-Delgado S, Sobrino C, Marugán-Cruz C. Defluidization and agglomeration of a fluidized bed reactor during Cynara cardunculus L. gasification using sepiolite as a bed material. Fuel Process Technol 2015;131:338-47. doi:10.1016/j.fuproc.2014.11.036.

[15] Öhman M, Pommer L, Nordin A. Bed agglomeration characteristics and mechanisms during gasification and combustion of biomass fuels. Energy and Fuels 2005;19:1742-8. doi:10.1021/ef040093w. 
[16] Khan a. a., de Jong W, Jansens PJ, Spliethoff H. Biomass combustion in fluidized bed boilers: Potential problems and remedies. Fuel Process Technol 2009;90:21-50. doi:10.1016/j.fuproc.2008.07.012.

[17] Hupa M. Ash-related issues in fluidized-bed combustion of biomasses: Recent research highlights. Energy and Fuels 2012;26:4-14. doi:10.1021/ef201169k.

[18] Vamvuka D, Pitharoulis M, Alevizos G, Repouskou E, Pentari D. Ash effects during combustion of lignite/biomass blends in fluidized bed. Renew Energy 2009;34:2662-71. doi:10.1016/j.renene.2009.05.005.

[19] Shao Y, Wang J, Preto F, Zhu J, Xu C. Ash deposition in biomass combustion or co-firing for power/heat generation. Energies 2012;5:517189. doi:10.3390/en5125171.

[20] Bashir MS, Jensen PA, Frandsen F, Wedel S, Dam-Johansen K, Wadenbäck J, et al. Ash transformation and deposit build-up during biomass suspension and grate firing: Full-scale experimental studies. Fuel Process Technol 2012;97:93-106. doi:10.1016/j.fuproc.2012.01.018.

[21] Miles TR, Miles TR, Baxter LL, Bryers RW, Jenkins BM, Oden LL. Boiler deposits from firing biomass fuels. Biomass and Bioenergy 1996;10:12538. doi:10.1016/0961-9534(95)00067-4.

[22] Jensen PA, Frandsen FJ, Hansen J, Dam-Johansen K, Henrisken N, Hörlyck S. SEM investigation of superheater deposits from biomass-fired boilers. Energy and Fuels 2004;18:378-84. doi:10.1021/ef030097l.

[23] Li G, Li S, Xu X, Huang Q, Yao Q. Dynamic behavior of biomass ash deposition in a $25 \mathrm{~kW}$ one-dimensional down-fired combustor. Energy and Fuels 2014;28:219-27. doi:10.1021/ef401530a.

[24] Tranvik a. C, Öhman M, Sanati M. Bed material deposition in cyclones of wood fuel fired circulating fluidized beds (CFBs). Energy and Fuels 2007;21:104-9. doi:10.1021/ef060175f.

[25] Öhman M, Nordin a., Hedman H, Jirjis R. Reasons for slagging during stemwood pellet combustion and some measures for prevention. Biomass and Bioenergy 2004;27:597-605. doi:10.1016/j.biombioe.2003.08.017.

[26] Xiong S, Burvall J, Örberg H, Kalen G, Thyrel M, Öhman M, et al. Slagging characteristics during combustion of corn stovers with and without kaolin and calcite. Energy and Fuels 2008;22:3465-70. doi:10.1021/ef700718j. 
[27] Lindström E, Öhman M, Backman R, Boström D. Influence of sand contamination on slag formation during combustion of wood derived fuels. Energy and Fuels 2008;22:2216-20. doi:10.1021/ef700772q.

[28] Kirnbauer $\mathrm{F}$, Hofbauer $\mathrm{H}$. The mechanism of bed material coating in dual fluidized bed biomass steam gasification plants and its impact on plant optimization. Powder Technol 2013;245:94-104. doi:10.1016/j.powtec.2013.04.022.

[29] Kirnbauer F, Hofbauer H. Investigations on bed material changes in a dual fluidized bed steam gasification plant in Güssing, Austria. Energy and Fuels 2011;25:3793-8. doi:10.1021/ef200746c.

[30] Kirnbauer F, Wilk V, Kitzler H, Kern S, Hofbauer $\mathrm{H}$. The positive effects of bed material coating on tar reduction in a dual fluidized bed gasifier. Fuel 2012;95:553-62. doi:10.1016/j.fuel.2011.10.066.

[31] Kern S, Pfeifer C, Hofbauer H. Reactivity tests of the water-gas shift reaction on fresh and used fluidized bed materials from industrial DFB biomass gasifiers. Biomass and Bioenergy 2013;55:227-33. doi:10.1016/j.biombioe.2013.02.001.

[32] Kaltschmitt M, Hartmann $\mathrm{H}$, Hofbauer H. Energie aus Biomasse. Berlin, Heidelberg: Springer Berlin Heidelberg; 2001. doi:10.1007/978-3-66207025-3.

[33] Roedder E. Silicate melt systems. Phys Chem Earth 1959;3:224-97. doi:10.1016/0079-1946(59)90007-2.

[34] Scala F, Chirone R. An SEM/EDX study of bed agglomerates formed during fluidized bed combustion of three biomass fuels. Biomass and Bioenergy 2008;32:252-66. doi:10.1016/j.biombioe.2007.09.009. 
681 Figure 1: Basic flow chart of the dual fluid bed gasification process in

682 Ulm/Senden; (1) recirculation of coarse ash and fly coke and addition of fresh

683 olivine, (2) recirculation of product gas

684 Figure 2: ESEM image of deposits

685 Figure 3: ESEM image of bed material

686 Figure 4: ESEM image of coarse ash

687 Figure 5: ESEM image of cracks in the olivine bed particle layers

688 Figure 6: ESEM image of breakage areas of the olivine bed particle layers

689

690

691

692

693

694

695

696

697

698

699

700

701

702

703

704 
Elements $\mathrm{C}, \mathrm{H}, \mathrm{N}, \mathrm{O}, \mathrm{K}, \mathrm{Na}, \mathrm{Ca}, \mathrm{Mg}, \mathrm{Si}, \mathrm{Fe}, \mathrm{Al}$

Slag: SLAGA (MgO, $\mathrm{SiO}_{2}, \mathrm{CaO}, \mathrm{K}_{2} \mathrm{O}, \mathrm{Fe}_{2} \mathrm{O}_{3}, \mathrm{FeO}, \mathrm{Al}_{2} \mathrm{O}_{3}$ )

Olivine (Mg, $\left.\mathrm{Fe}, \mathrm{Ca} / / \mathrm{SiO}_{4}\right)$

Solution MulF (Mullite $\mathrm{Al}_{6} \mathrm{Si}_{2} \mathrm{O}_{13}, \mathrm{Fe}_{6} \mathrm{Si}_{2} \mathrm{O}_{13}$ )

models Mel (Melilite $\left.\mathrm{Ca}_{2} \mathrm{MgSi}_{2} \mathrm{O}_{7}, \mathrm{Ca}_{2} \mathrm{Al}_{2} \mathrm{SiO}_{7}, \mathrm{Ca} 2 \mathrm{FeSi} 2 \mathrm{O} 7, \mathrm{Ca} 2 \mathrm{Fe} 2 \mathrm{SiO} 7\right)$

Salt melt: MELTA (K, Na//CO $\mathrm{CO}_{3}, \mathrm{OH}$ salt melt)

$\mathrm{LCSO}\left(\mathrm{K}, \mathrm{Ca} / / \mathrm{CO}_{3}\right.$ melt $)$

$\mathrm{SCSO}\left(\mathrm{K}, \mathrm{Ca} / / \mathrm{CO}_{3}\right.$ solid solution)

708

709

710

711

712

713 


\begin{tabular}{lccccccc} 
Component & $\begin{array}{c}\text { Feedstock } \\
\text { ash } \\
\text { average }\end{array}$ & $\begin{array}{c}\text { Deposit } \\
\text { average }\end{array}$ & $\begin{array}{c}\text { Bed } \\
\text { material } \\
\text { average }\end{array}$ & $\begin{array}{c}\text { Coarse } \\
\text { ash } \\
\text { average }\end{array}$ & $\begin{array}{c}\text { Fine } \\
\text { ash } \\
\text { average }\end{array}$ & $\begin{array}{c}\text { Fly coke } \\
\text { average }\end{array}$ & $\begin{array}{c}\text { Impurities } \\
\text { average }\end{array}$ \\
\hline [wt\%] & [wt\%] & [wt\%] & [wt\%] & [wt\%] & [wt\%] & [wt\%] \\
\hline $\mathrm{NiO}$ & $0.0 \%$ & $0.0 \%$ & $0.2 \%$ & $0.2 \%$ & $0.0 \%$ & $0.2 \%$ & $1.6 \%$ \\
$\mathrm{Fe}_{2} \mathrm{O}_{3}$ & $0.7 \%$ & $2.4 \%$ & $6.8 \%$ & $6.3 \%$ & $2.0 \%$ & $6.5 \%$ & $2.5 \%$ \\
$\mathrm{Cr}_{2} \mathrm{O}_{3}$ & $0.0 \%$ & $0.1 \%$ & $0.2 \%$ & $0.2 \%$ & $0.1 \%$ & $0.2 \%$ & $0.6 \%$ \\
$\mathrm{CaO} \mathrm{O}$ & $55.6 \%$ & $34.0 \%$ & $13.8 \%$ & $11.0 \%$ & $54.6 \%$ & $16.5 \%$ & $22.9 \%$ \\
$\mathrm{~K}_{2} \mathrm{O}$ & $12.6 \%$ & $5.1 \%$ & $0.7 \%$ & $0.9 \%$ & $2.9 \%$ & $0.9 \%$ & $8.2 \%$ \\
$\mathrm{SO}_{3}$ & $2.9 \%$ & $0.1 \%$ & $0.1 \%$ & $0.1 \%$ & $0.4 \%$ & $0.1 \%$ & $0.3 \%$ \\
$\mathrm{P}_{2} \mathrm{O}_{5}$ & $4.8 \%$ & $0.9 \%$ & $0.3 \%$ & $0.3 \%$ & $1.5 \%$ & $0.3 \%$ & $0.4 \%$ \\
$\mathrm{SiO}_{2}$ & $13.4 \%$ & $40.8 \%$ & $34.3 \%$ & $38.1 \%$ & $22.8 \%$ & $34.6 \%$ & $47.0 \%$ \\
$\mathrm{Al}_{2} \mathrm{O}_{3}$ & $3.3 \%$ & $4.3 \%$ & $0.9 \%$ & $1.1 \%$ & $3.1 \%$ & $1.0 \%$ & $5.6 \%$ \\
$\mathrm{MgO}$ & $5.0 \%$ & $10.5 \%$ & $39.5 \%$ & $40.5 \%$ & $10.3 \%$ & $38.2 \%$ & $4.7 \%$ \\
$\mathrm{Na}_{2} \mathrm{O}$ & $0.8 \%$ & $1.1 \%$ & $2.2 \%$ & $0.8 \%$ & $1.0 \%$ & $0.9 \%$ & $3.9 \%$ \\
Others & $0.8 \%$ & $0.8 \%$ & $0.8 \%$ & $0.5 \%$ & $1.2 \%$ & $0.6 \%$ & $2.3 \%$ \\
\hline & $100.0 \%$ & $100.0 \%$ & $100.0 \%$ & $100.0 \%$ & $100.0 \%$ & $100.0 \%$ & $100.0 \%$
\end{tabular}




\begin{tabular}{|c|c|c|c|c|c|c|}
\hline & & $\begin{array}{l}\text { Deposit } \\
\text { average }\end{array}$ & $\begin{array}{c}\text { Bed } \\
\text { material } \\
\text { average }\end{array}$ & $\begin{array}{c}\text { Coarse } \\
\text { ash } \\
\text { average }\end{array}$ & $\begin{array}{c}\text { Fine ash } \\
\text { average }\end{array}$ & $\begin{array}{l}\text { Fly coke } \\
\text { average }\end{array}$ \\
\hline & & [wt\%] & [wt\%] & [wt\%] & [wt\%] & [wt\%] \\
\hline quartz & $\mathrm{SiO}_{2}$ & 1.0 & 3 & 4 & 1.5 & 4 \\
\hline microcline & $\mathrm{KAISi}_{3} \mathrm{O}_{8}$ & n.d. & n.d. & n.d. & n.d. & 2 \\
\hline forsterite(Fe) & $\mathrm{Mg}_{2} \mathrm{SiO}_{4}$ & 5.0 & 76.5 & 69.5 & n.d. & 32.5 \\
\hline lime & $\mathrm{CaO}$ & n.d. & 3.5 & 6.5 & 27.5 & 3.5 \\
\hline periclase & $\mathrm{MgO}$ & 1.5 & 3 & 5 & 4 & 2.5 \\
\hline portlandite & $\mathrm{Ca}(\mathrm{OH})_{2}$ & 2.0 & n.d. & n.d. & n.d. & 15 \\
\hline calcite & $\mathrm{CaCO}_{3}$ & 2.0 & 1.5 & n.d. & 45.5 & 21.5 \\
\hline fairchildite & $\mathrm{CaK}_{2}\left(\mathrm{CO}_{3}\right)_{2}$ & n.d. & n.d. & n.d. & n.d. & n.d. \\
\hline anhydrite & $\mathrm{CaSO}_{4}$ & 2.0 & n.d. & n.d. & n.d. & n.d. \\
\hline gypsum & $\mathrm{CaSO}_{4} \times 2 \mathrm{H}_{2} \mathrm{O}$ & 2.0 & n.d. & n.d. & n.d. & n.d. \\
\hline archanite & $\mathrm{K}_{2} \mathrm{SO}_{4}$ & n.d. & 1.5 & 1.5 & n.d. & n.d. \\
\hline apathite & $\mathrm{Ca}_{5}\left(\mathrm{PO}_{4}\right)_{3}(\mathrm{OH})$ & 1.0 & n.d. & n.d. & 1.5 & 1 \\
\hline larnite & $\mathrm{Ca}_{2} \mathrm{SiO}_{4}$ & 5.3 & 4 & 4.5 & 5.5 & 4.5 \\
\hline wollastonite & $\mathrm{CaSiO}_{3}$ & 15.7 & n.d. & n.d. & n.d. & n.d. \\
\hline rankinite & $\mathrm{Ca}_{3} \mathrm{Si}_{2} \mathrm{O}_{7}$ & 8.7 & n.d. & n.d. & n.d. & n.d. \\
\hline akermanite & $\mathrm{Ca}_{2} \mathrm{MgSi}_{2} \mathrm{O}_{7}$ & 21.0 & n.d. & n.d. & n.d. & n.d. \\
\hline merwinite & $\mathrm{Ca}_{3} \mathrm{Mg}\left(\mathrm{SiO}_{4}\right)_{2}$ & 8.0 & 2.5 & 3 & 5.5 & 2.5 \\
\hline bredigite & $\mathrm{Ca}_{7} \mathrm{Mg}\left(\mathrm{SiO}_{4}\right)_{4}$ & 10.0 & 1.5 & 1 & 5 & 2.5 \\
\hline kalsilite & $\begin{array}{l}\mathrm{KAISiO}_{4} \\
\mathrm{~K}_{2} \mathrm{MgSiO}_{4} \\
\mathrm{~K}_{2} \mathrm{MgSi}_{5} \mathrm{O}_{12}\end{array}$ & $\begin{array}{l}9.3 \\
2.5 \\
2.0\end{array}$ & $\begin{array}{c}1 \\
1 \\
\text { n.d. }\end{array}$ & $\begin{array}{l}\text { n.d. } \\
2.5 \\
\text { n.d. }\end{array}$ & $\begin{array}{c}2 \\
\text { n.d. } \\
\text { n.d. }\end{array}$ & $\begin{array}{l}3.5 \\
\text { n.d. } \\
\text { n.d. }\end{array}$ \\
\hline hematite & $\mathrm{Fe}_{2} \mathrm{O}_{3}$ & 1.0 & n.d. & n.d. & 1 & 2 \\
\hline maghemite & $\mathrm{Fe}_{2} \mathrm{O}_{3}$ & n.d. & 1 & 1.5 & 1 & 3 \\
\hline magnetite & $\mathrm{Fe}_{3} \mathrm{O}_{4}$ & n.d. & n.d. & n.d. & n.d. & n.d. \\
\hline cristobalite & $\mathrm{SiO}_{2}$ & n.d. & n.d. & 1 & n.d. & n.d. \\
\hline
\end{tabular}
not detected

n.d.

$\begin{array}{cccccc}\text { SUM } & 100.0 & 100.0 & 100.0 & 100.0 & 100.0 \\ \text { Table 3: Crystalline phases identified with XRD analysis } & \end{array}$

740

741

742

743

744

745 


\begin{tabular}{|c|c|c|c|c|c|c|}
\hline & Particle & Layer & $\begin{array}{l}\text { Deposit } \\
\text { fragments A }\end{array}$ & $\begin{array}{l}\text { Deposit } \\
\text { fragments B }\end{array}$ & $\begin{array}{l}\text { Deposit } \\
\text { fragments C }\end{array}$ & $\begin{array}{l}\text { Deposit } \\
\text { fragments D }\end{array}$ \\
\hline & & [wt\%] & [wt\%] & [wt\%] & [wt\%] & [wt\%] \\
\hline $\mathrm{Na}$ & $1.9(+/-0.1)$ & $1.1(+/-0.1)$ & $1.3(+/-0.3)$ & $1.1(+/-0.2)$ & $0.8 \quad(+/-0.2)$ & $0.3(+/-0.1)$ \\
\hline Mg & $41.7(+/-1,1)$ & $13.0(+/-0.2)$ & $11.4(+/-1.3)$ & $10.9(+/-0.5)$ & $5.2(+/-1.0)$ & $1.3(+/-0.2)$ \\
\hline Al & $1.2(+/-0.1)$ & $1.9(+/-0.5)$ & $3.7(+/-0.4)$ & $1.9(+/-0.2)$ & $9.2(+/-0.9)$ & $1.6(+/-0.3)$ \\
\hline Si & $37.6(+/-0.4)$ & $27.3(+/-0.5)$ & $31.0(+/-0.8)$ & $34.1(+/-1.2)$ & $34.1(+/-0.9)$ & $37.4(+/-1.5)$ \\
\hline $\mathbf{P}$ & $0.4(+/-0.1)$ & $0.5 \quad(+/-0.0)$ & $1.2(+/-0.2)$ & $0.8 \quad(+/-0.2)$ & $0.5(+/-0.0)$ & $0.6(+/-0.1)$ \\
\hline $\mathbf{S}$ & $0.2(+/-0.0)$ & $0.1 \quad(+/-0.1)$ & $0.3 \quad(+/-0.2)$ & $0.1 \quad(+/-0.1)$ & $0.2(+/-0.1)$ & $0.1 \quad(+/-0.1)$ \\
\hline Cl & $0.4 \quad(+/-0.0)$ & $0.5(+/-0.1)$ & $1.9(+/-0.8)$ & $0.4(+/-0.1)$ & $0.4 \quad(+/-0.1)$ & $0.3(+/-0.1)$ \\
\hline K & $1.5(+/-0.4)$ & $1.6(+/-0.4)$ & $7.7 \quad(+/-0.9)$ & $2.8 \quad(+/-0.4)$ & $16.9(+/-1.1)$ & $3.1 \quad(+/-0.7)$ \\
\hline $\mathrm{Ca}$ & $9.1 \quad(+/-2.6)$ & $47.6(+/-2.7)$ & $36.0(+/-2.5)$ & $45.5(+/-1.8)$ & $26.6(+/-2.4)$ & $53.6(+/-1.8)$ \\
\hline Mn & $0.6(+/-0.0)$ & $0.7 \quad(+/-0.2)$ & $0.7 \quad(+/-0.1)$ & $0.5(+/-0.1)$ & $0.5(+/-0.1)$ & $0.5(+/-0.1)$ \\
\hline $\mathrm{Fe}$ & $9.6(+/-1.4)$ & $5.7 \quad(+/-2.2)$ & $4.9(+/-0.7)$ & $1.9(+/-0.2)$ & $5.7(+/-0.8)$ & $1.0(+/-0.2)$ \\
\hline
\end{tabular}

749

750

751

752

753

754

755

756

757

758

759

760

761

762

763 
Deposit Attached melt

fragments A fragments

\begin{tabular}{|c|c|c|}
\hline & [wt\%] & [wt\%] \\
\hline $\mathrm{Na}$ & $1.3(+/-0.3)$ & $0.2(+/-0.2)$ \\
\hline Mg & $11.4(+/-1.3)$ & $11.0(+/-1.0)$ \\
\hline Al & $3.7(+/-0.4)$ & $3.6(+/-1.0)$ \\
\hline Si & $31.0(+/-0.8)$ & $30.9(+/-1.2)$ \\
\hline $\mathbf{P}$ & $1.2(+/-0.2)$ & $0.6(+/-0.1)$ \\
\hline $\mathbf{S}$ & $0.3(+/-0.2)$ & $0.2(+/-0.0)$ \\
\hline Cl & $1.9(+/-0.8)$ & $0.4 \quad(+/-0.1)$ \\
\hline K & $7.7 \quad(+/-0.9)$ & $7.4 \quad(+/-1.1)$ \\
\hline $\mathrm{Ca}$ & $36.0(+/-2.5)$ & $40.7(+/-1.4)$ \\
\hline Mn & $0.7(+/-0.1)$ & $0.5(+/-0.1)$ \\
\hline $\mathrm{Fe}$ & $4.9(+/-0.7)$ & $3.7(+/-0.6)$ \\
\hline
\end{tabular}

766

767

768

769

770

771

772

773

774

775

776

777

778

779

780

781 


\begin{tabular}{|c|c|c|c|c|c|c|c|c|c|}
\hline & [wt\%] & & [wt\%] & & [wt\%] & & [wt\%] & [wt\%] & [wt\%] \\
\hline $\mathrm{Na}$ & $1.4(+/-0.0)$ & 0.3 & $(+/-0.2)$ & 0.9 & & 0.7 & & $1.5(+/-0$ & $1.1(+/-0.1)$ \\
\hline Mg & $29.6(+/-0.5)$ & 9.2 & $-(-0.4)$ & 3.9 & & 3.7 & (- 0.5$)$ & $5.0 \quad(+/$ & $6.5(+/$ \\
\hline Al & $0.6(+/-0.1)$ & 0.5 & $(+/-0.3)$ & 3.2 & $(+/-0.2)$ & 3.5 & $(+/-0.1)$ & $3.2(+/-0.8)$ & $12.0(+/-0.1)$ \\
\hline Si & $18.5(+/-0.3)$ & 6.0 & $(+/-0.2)$ & 61.4 & $(+/-2$ & 42.1 & $(+/-1.3)$ & $55.9(+/-1.5)$ & $51.2(+/-0.8)$ \\
\hline $\mathbf{P}$ & $0.5(+/-0.0)$ & 2.0 & $(+/-0.2)$ & 0.1 & $(+/-0.0)$ & 0.7 & $(+/-0.0)$ & $0.3(+/-0.1)$ & $0.5(+/-0.1)$ \\
\hline S & $0.1 \quad(+/-0.0)$ & 0.1 & $(+/-0.0)$ & 0.2 & $(+/-0$ & 0.2 & $(+/-0$ & $(+/-0.0)$ & $(+/-0.0)$ \\
\hline $\mathrm{Cl}$ & $(+/-0.0)$ & 0.1 & $(+/-0.1)$ & 0.4 & $(+/-$ & 0.5 & ) & $0.6 \quad(+/-$ & $0.4(+/-0.1)$ \\
\hline K & $0.5(+/-0.4)$ & 0.6 & $(+/-0.1)$ & 20.0 & $(+/-1.0)$ & 6.7 & $(+/-0.5)$ & $19.7(+/-0.6)$ & $19.6(+/-1.7)$ \\
\hline $\mathrm{Ca}$ & $41.8(+/-0.3)$ & $75 . \varepsilon$ & $(+/-0.7)$ & 7.0 & $(+/-0.4)$ & 39.4 & $(+/-0.8)$ & $8.8(+/-1.2)$ & $5.6(+/-1.1)$ \\
\hline Mn & $1.3(+/-0.1)$ & 1.8 & $(+/-0.1)$ & 0.7 & $(+/-0.0)$ & 0.4 & $(+/-0.1)$ & $(+/-0.1)$ & $0.9(+/-0.1)$ \\
\hline $\mathrm{Fe}$ & $5.5(+/-0.4)$ & 3.5 & $(+/-0.2)$ & 1.6 & $(+/-0.6)$ & 1.8 & $(+/-0.4)$ & $(+/-0.9)$ & $2.3 \quad(+/-0.2)$ \\
\hline
\end{tabular}

Table 6: Average elemental compositions on a $\mathrm{C}$ - and $\mathrm{O}$ free basis in the bed and coarse ash samples

784

785

786

787

788

789 


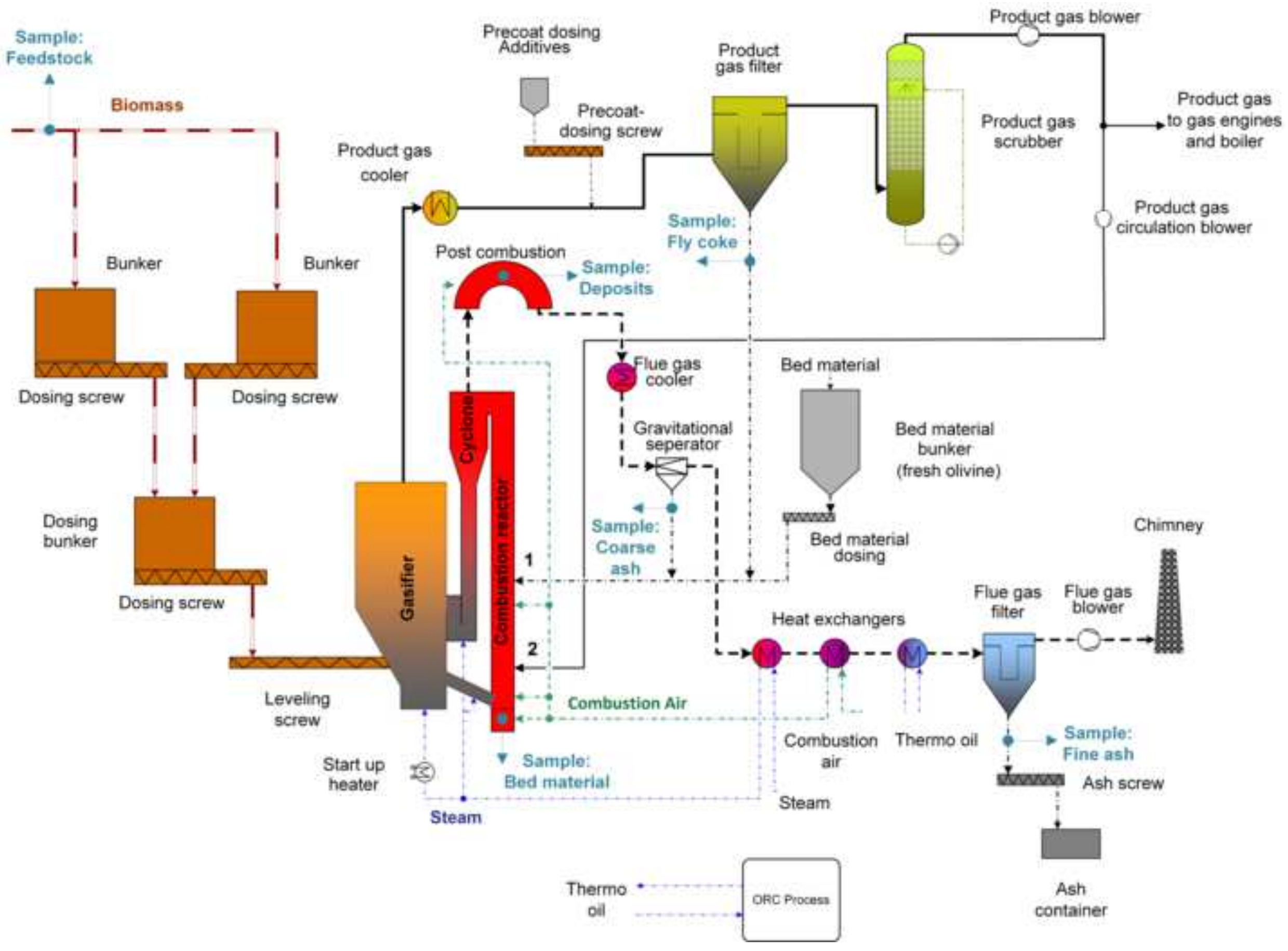


fragments. $\lim _{x \rightarrow i^{2}}$ $1, y^{2}$, Particle Ny?

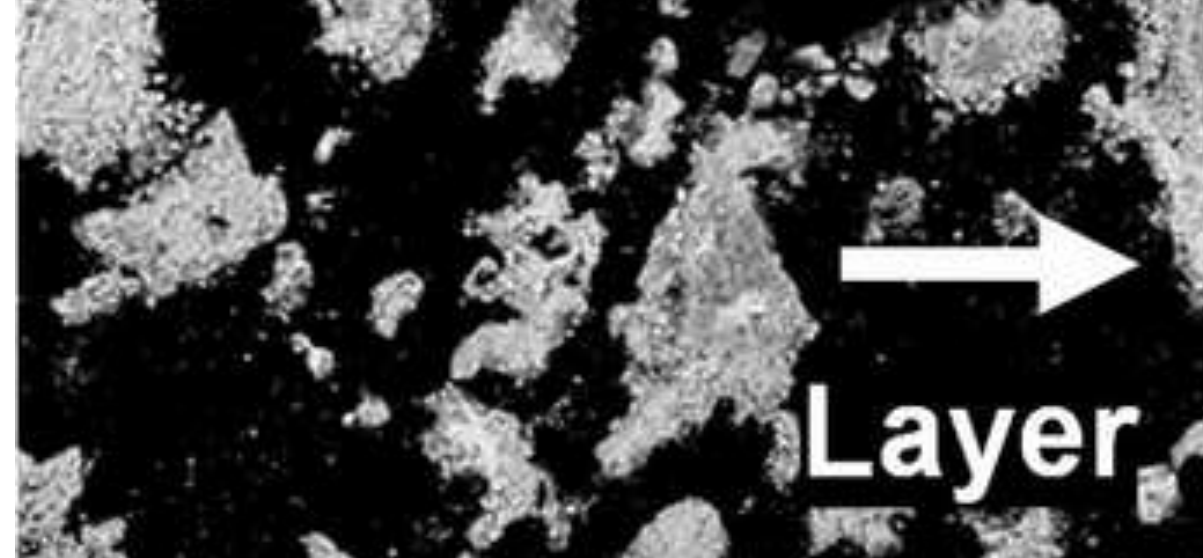

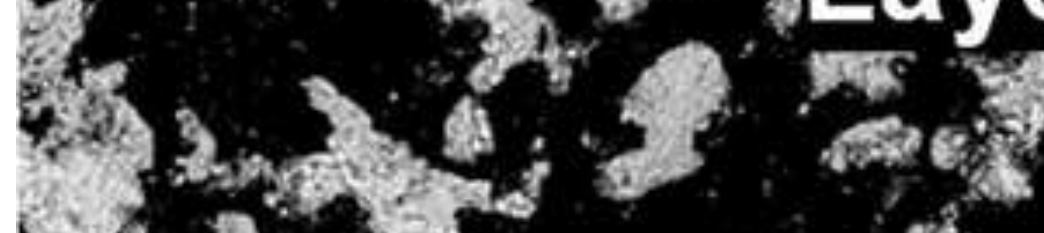

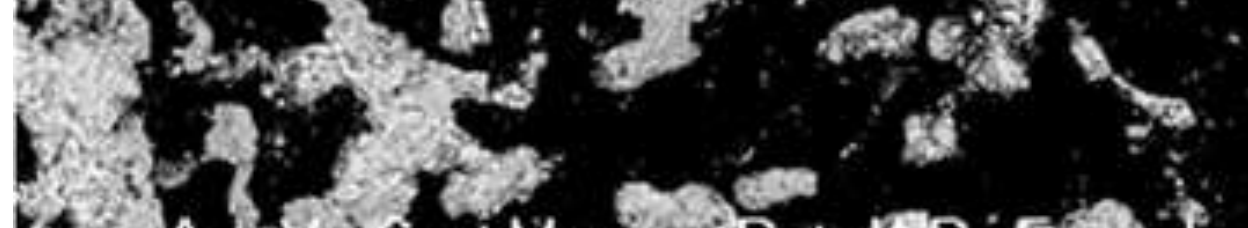

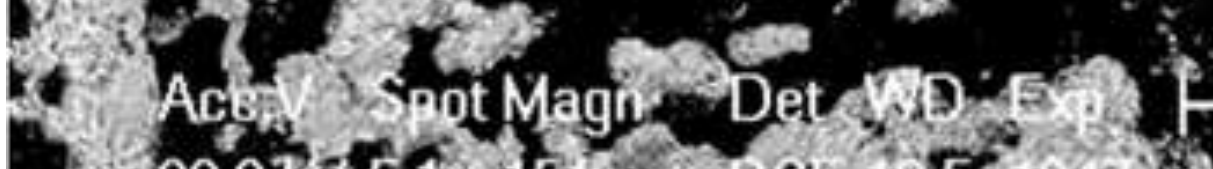

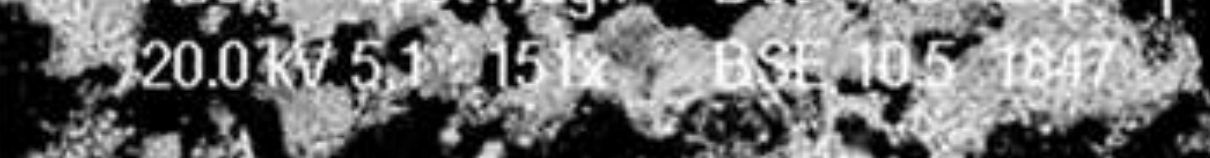

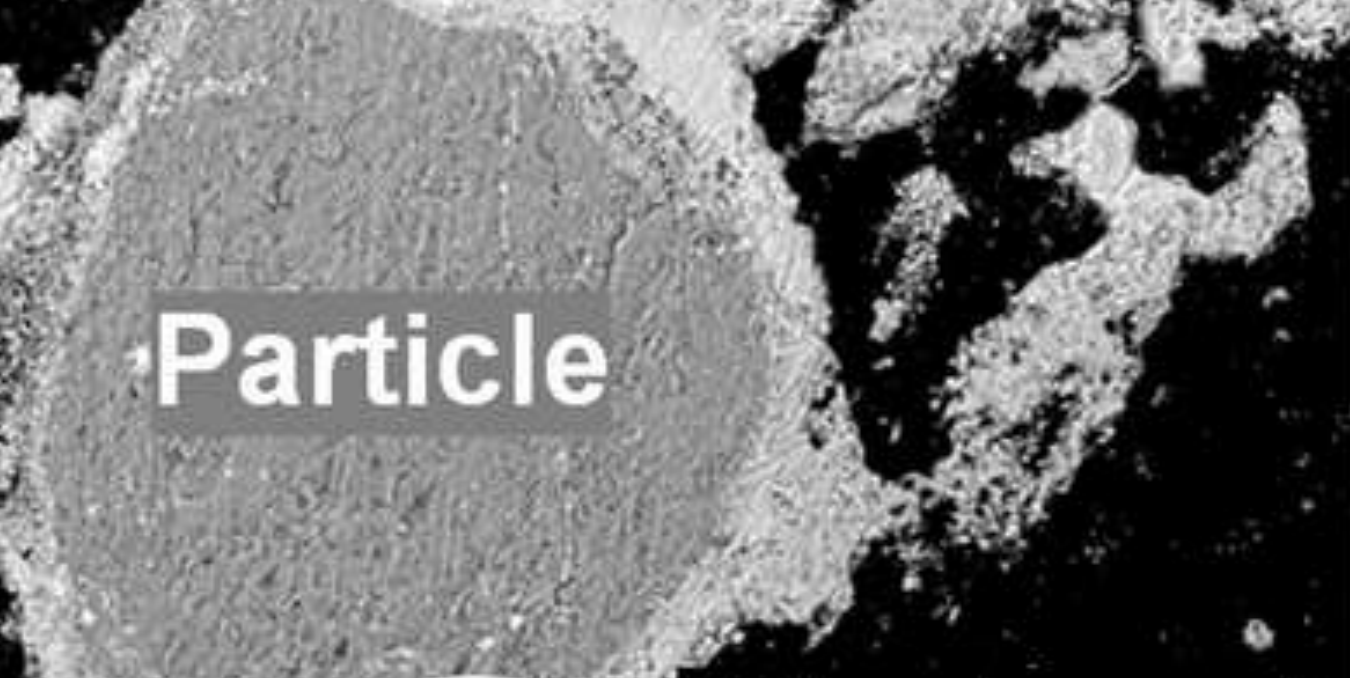
Attachment $(1)$ ( ) A. A $270^{4}$

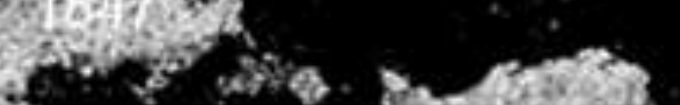
$\sin$ $-35$. 

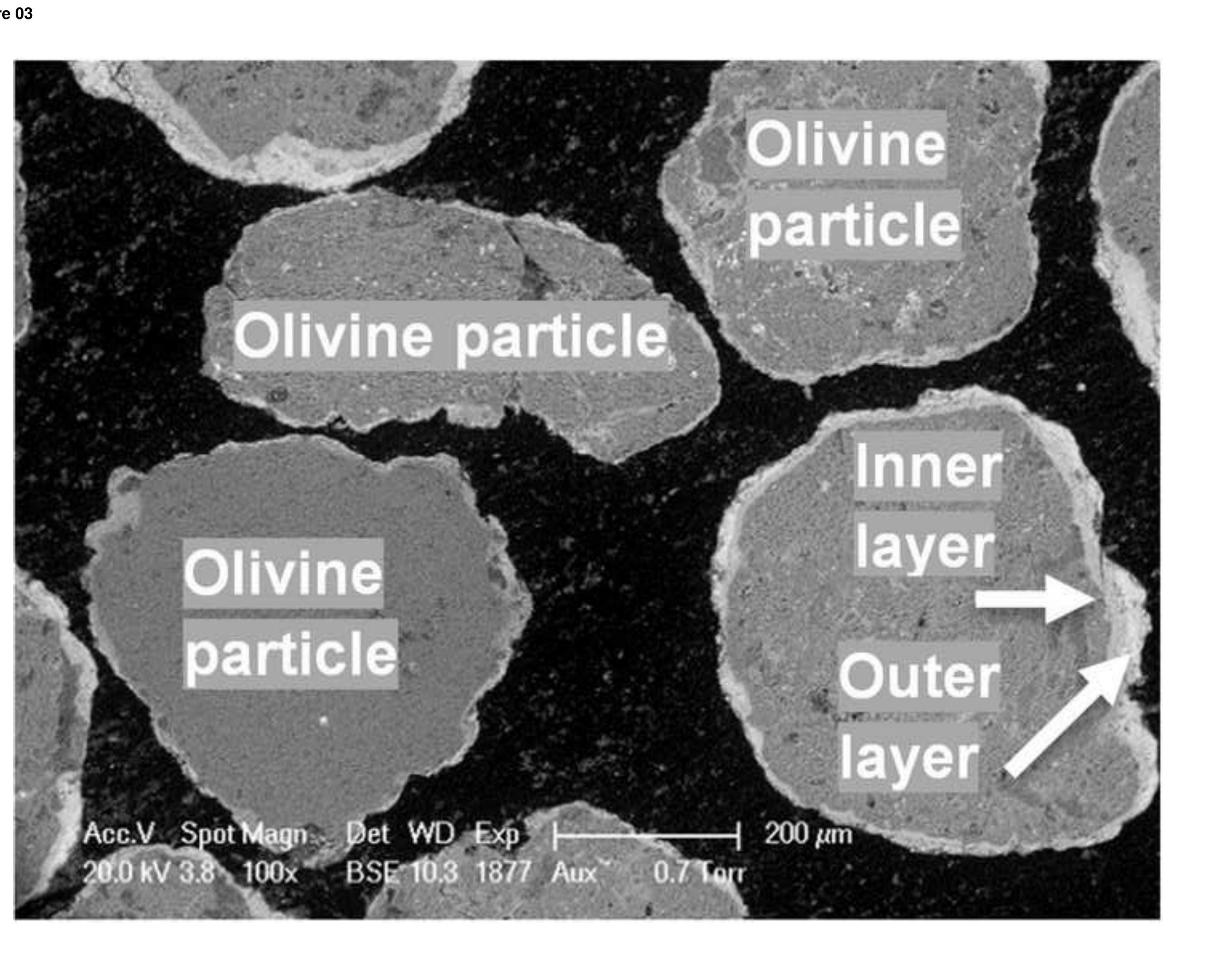


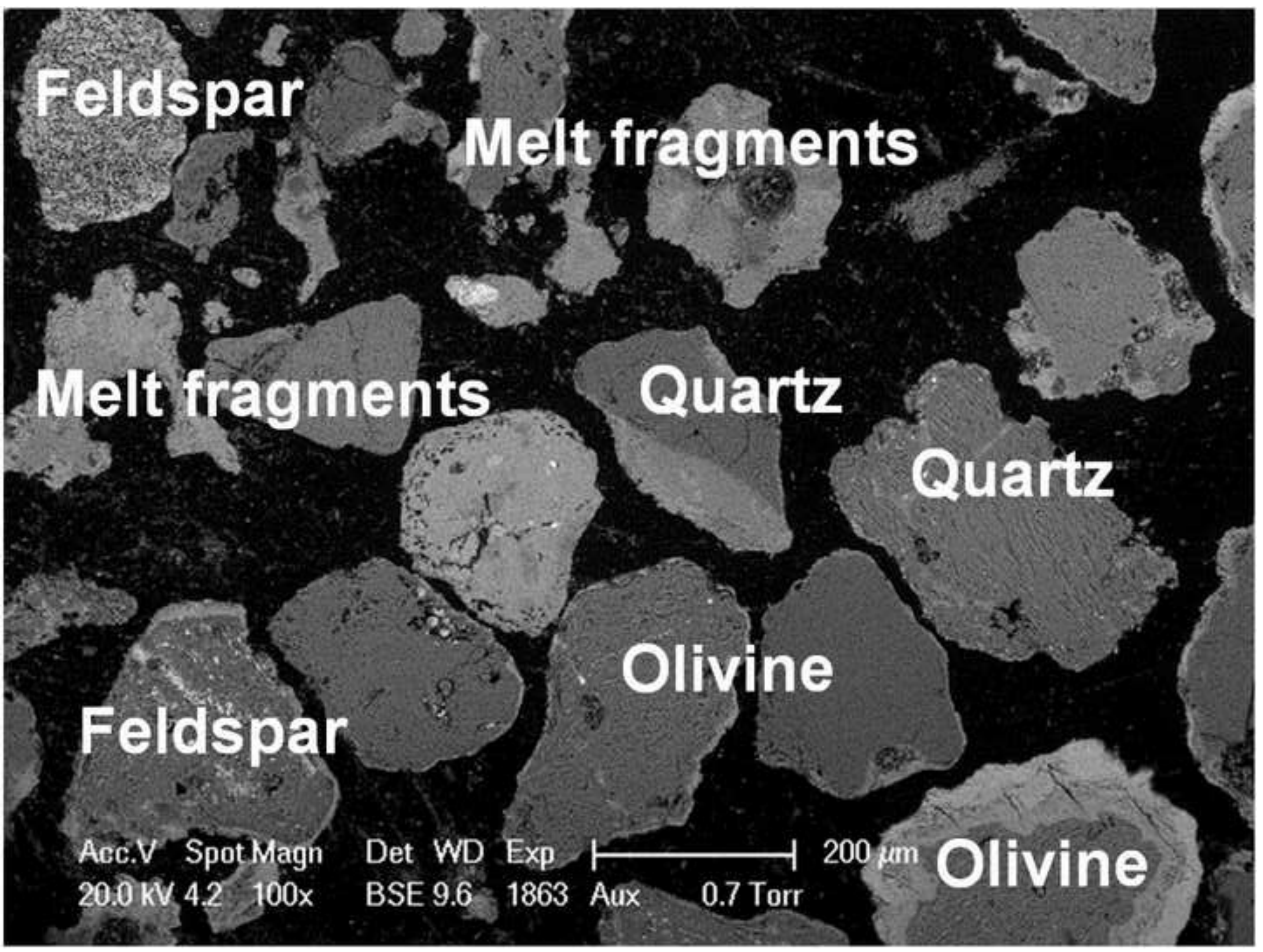

\section{Ferespar}

Melt ragments

Quartz

\section{Quartz}

Acc.V Spot Magn $20.0 \mathrm{kV} 4.2 \quad 100 \mathrm{x}$ BSE 9.6 1863 Aax $\quad 0.7$ Torr 


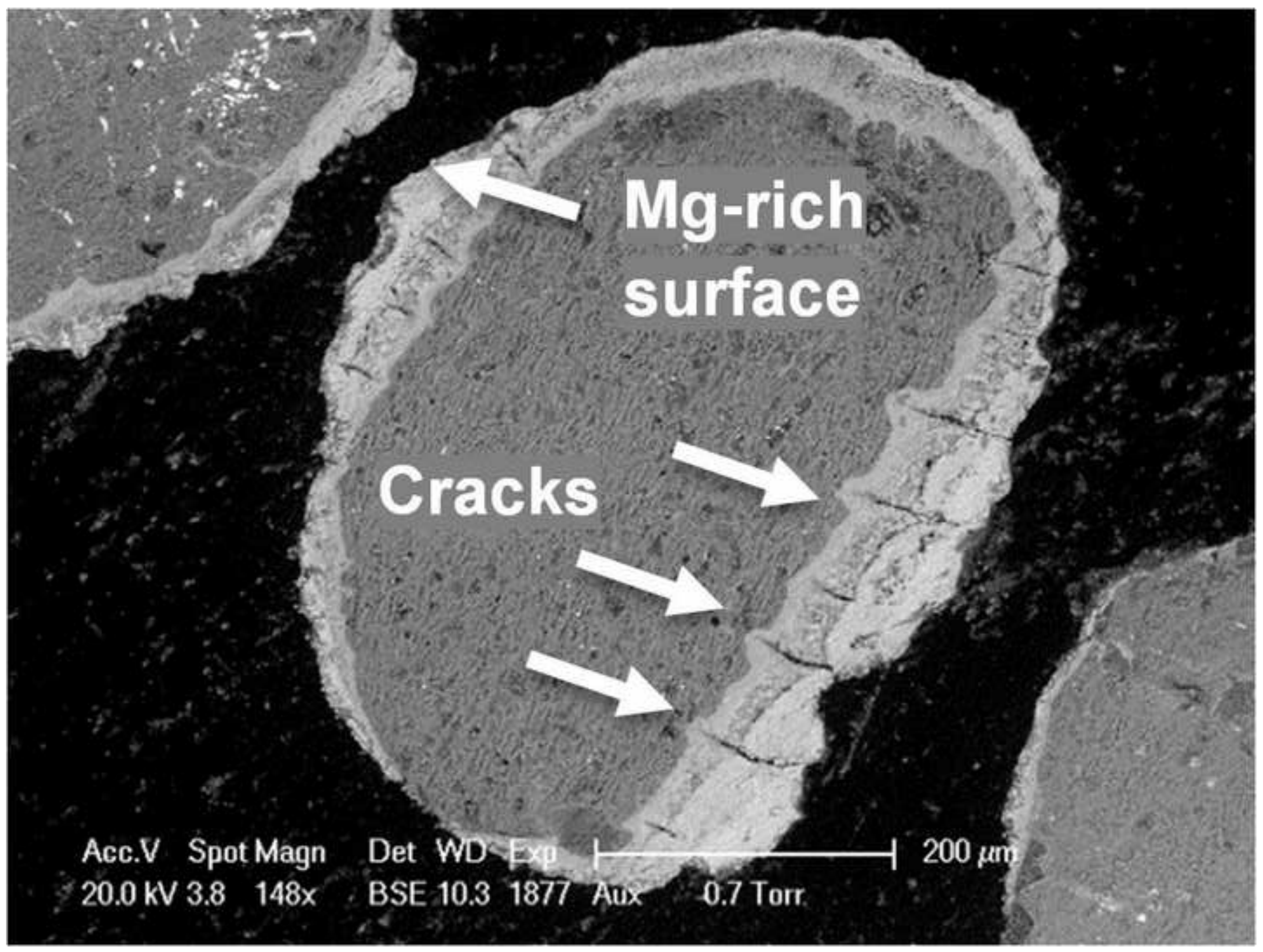

\section{Mg-rich: surface}

Acc.V SpotMagn Det Wo 20.0 kV 3.8 148x BSE 10.31877 Aux 
